\title{
THE EVALUATION OF FINANCIAL INSTRUMENTS
}

\author{
PhD student Marian Florin Aitai, aitaim@cjalba.ro \\ Alba County Council
}

Summary: The paper aims to present the initial and subsequent evaluation of the financial instruments; definition of the four categories of financial assets. Regarding the evaluation techniques, these must take into account the hypothesis that the market participants will use regarding the rate of the foresee payments, the rates of the losses from loans, the interest and the discount rates.

A financial instrument represents any contract that simultaneously generates a financial asset for one company and a financial debt or equity instrument for another company. Merchandise contracts, which allow any parts to reimburse cash or use another financial instrument, have to be registered into accountancy as financial instruments, excepting the concluded merchandise contracts which continue to satisfy the requirements of the company regarding the supply, sale and estimated consumption. Merchandise contracts were meant to this purpose from the beginning and it is supposed that the reimbursement is done at the merchandise delivery.

A financial asset is any asset representing:

- Cash,

- A contractual right to receive cash or another financial asset from another company,

- A contractual right to exchange financial instruments with another company under conditions that are potentially favorable,

- An equity instrument of another company.

The definition of the four categories of financial assets:

A financial asset (or a financial debt) possessed for transaction is an asset purchased or produced mainly for generating profit, as a result of a short-term fluctuations of price or intermediary's margin. A financial asset has to be classified as an asset possessed for transaction if, no matter the reason it was purchased, it is a part of a portfolio for which there is the proof of a recent effective rate to obtain short - term profits. Derivative financial instruments are always considered to be kept for transaction if they are not designated, and actually they are not, as instruments for covering the risk.

Investments kept until maturity are financial assets with fix or determinable payments and fixed maturity which a company has the opportunity and firm intention to keep until maturity.

Loans and debts issued by a company are financial assets produced by the company as a result of money, merchandise or services' delivery direct to a debtor, other then those initiated for immediate or short - term sale which have to be classified and kept for transaction. Loans and debts issued by a company are not included in investments kept until maturity, but they are separately classified in this Standard.

Financial assets available for sale are those financial assets which are not loans and debts produced by the company, investments kept until maturity or assets possessed for transaction. 


\section{The initial evaluation}

The initial evaluation is done when a financial asset or debt is initially recognized and the cost has to be evaluated or, what means the fair value of the payment offered (in the asset case) or received (in the debt case).

Transaction costs are included in the initial evaluation of all financial assets or debts.

\section{The subsequent evaluation of the financial assets}

The subsequent evaluation of the financial assets is carried out after the initial examination, by the evaluation of financial assets at their fair value, including the derivative instruments representing assets, without any deduction of transaction costs that might appear after sale or other exit, excepting the categories of financial assets presented below.

The fair value represents the amount an asset can be transitioned or the amount a debt can be willingly deducted between parts within a transaction where the price is objectively determined.

The fair value of the counter conscription offered or received can be normally determined by referring to the transaction price or other market prices. Whether these market prices can not be determined in a credible way, the fair value of a counter conscription is estimated to be equal to the sum of all future payments and receipts, up to date if the result is significant, using the interest rate (rates) preponderant on the market for a similar instrument (concerning the currency, the term, the type of interest rate and other factors) of an issuer classified in the same credit category.

The following categories of financial assets are differently evaluated (at their nominal cost);

From the point of view of the evaluation of a financial asset after the initial examination, the Standard 39 classifies financial assets into four categories:

- $\quad$ loans and debts issued by a company which are not kept for transactional reasons;

- $\quad$ investments kept until maturity;

- $\quad$ financial assets available for sale and

- $\quad$ financial assets kept for transactional reasons.

After the initial examination, a company has to evaluate the financial assets, including the derivative instruments representing assets at their fair value, without any deduction of transaction costs that might appear after sale or other exit excepting the following categories of financial assets that should be evaluated according to paragraph 73 from Standard 39:

a) loans and debts made by the company and which are not kept for transactional reasons;

b) investments kept until maturity;

c) all financial assets not having a price quoted on an active market whose fair value can not be evaluated in a credible way.

Financial assets not being designed as covering elements against risks are subject for evaluation according to the provisions of the accountancy's covering operations against risks.

There is the assumption that the fair value can be determined in a credible way for most of the financial assets classified as available for sale or kept for transacting. Despite all these, this assumption can be wrong for an investment in an instrument of capitals (including an investment representing an instrument of its equity capitals not having a price quoted on an active market for which other methods of reasonable estimation of the fair value are obviously inadequate or inoperable). The assumption can also be wrong for a derivative instrument attached to this instrument of its equity capitals that has to be reimbursed by its remittance. An example of investment representing an instrument of equity capitals are the special rights of participating without the specified date of payment whose profitability is linked to the companies' results. 
If a financial asset has to be evaluated at its fair value, and its fair value is negative, it is registered in accountancy as a financial debt.

Those financial debts excluded from the evaluation by the value having a settled due date have to be evaluated at their paid-back cost using the interest rate method. Those having not a settled falling date have to be quantified at their cost.

The short-term debts without a settled interest rate are normally evaluated at the invoice initial value excepting the case the assignment of an implicit interest doesn't have a significant result.

The loans and the debts of a certain company which are not kept for transacting are evaluated at their paid-back cost, no matter the company's intention to keep them or not until maturity.

Regarding the financial instruments having a varying interest, the recurrent new estimation of the cash flow in order to reflect the evolution of the interests on the market changes the effective efficiency of a financial monetary asset. Such changes of the cash flow have to be acknowledged during the period left until the date of payment of the asset or until the next price restoration date if the price of the asset is reestablished at the market price. If a financial asset having a varying interest admitted initially at a value equivalent to the nominal cost of the principal payable at maturity, the reestablishment of the future interest payments does not normally have a significant effect over the book value of the asset.

A company applies The results of the rate exchange variation for certain financial assets representing the monetary elements that are expressed in a foreign currency. According to the IAS 21 (State Agricultural Enterprises 21), all profit and losses from the rate exchange corresponding to the monetary asset influence the net profit or the net loss excepting the case the monetary element is designed as a covering instrument against the risks in a covering operation of the cash flow. The exchange rate differences resulted from operations undergone during the year, at the existent rate at the operation rate will be registered in the revenue account, respectively in the expenses account and they will not be taken into account at the income tax settlement until the end of the year. At the end of the year, taxes will be levied on the re-evaluation and the regularizations of the rate differences according to the fiscal regulations.

All financial assets are subject to analysis regarding the devaluation.

\section{Investments kept until maturity}

A company has not the declared intention of keeping until maturity an investment in a financial asset having a fixed maturity date if any of the following conditions is satisfied:

a) the company does not have the intention of keeping the financial asset but for a defined period

b) the company is ready to sell the financial asset (excepting the case a singular unrepeatable situation showed up which could not be reasonably anticipated by the company) as a result of some changes of both the interest on the market or the risks, of some need for liquidities, of some changes in the sources and financing conditions or the currency risks; or

c) the issuer has the right to recover the financial asset at a value far below its depreciated cost.

A debt security having a variable rate can satisfy the criteria for an investment kept until maturity. Most of the equity capital securities can not be investments kept until maturity either because they do not have a well-defined lifetime (such as common shares), or because the sums the shareholder might receive can vary in an undetermined manner (such as the share options, subscription receipts and rights). By investments we understand fixed or determinable payments and by fixed date of payment a contractual agreement settling the values and terms of payment to the holder, such as interest payments and the principal corresponding to the debts. 
A financial asset redeemable by the issuer satisfies the criteria for an investment kept until maturity if the issuer substantially recovers all its book value. If practiced, the buying option speeds up only the maturity date of the asset. Despite all these, if the financial asset is redeemable in such conditions that the holder does not substantially recover all its book value, the financial asset can not be classified as kept until maturity date. In order to determine if the book value will be substantially recovered, the company will take into account all payments and the included transaction costs.

A redeemable financial asset at the investor's initiative (the holder has the right to ask the issuer to reimburse or to redeem the financial asset before maturity) can be classified as instrument kept until maturity only if the holder has the declared intention and the ability to keep it until maturity and he does not exercise the redemption clause before maturity.

A company does not have to classify any financial asset as kept until maturity if, during the current financial exercise or during two anterior financial exercises, the company sold, transferred or exercised before maturity date a sale option on a bigger value than a insignificant one of investments kept until maturity (bigger than an insignificant one as compared to the total portfolio kept until maturity), others than:

a) sales made close enough of the signing date or the sale option exercising date, so that the interest rate changes on the market did not have a significant effect upon the fair value of the financial asset;

b) sales made after the company already substantially cashed the principal of all financial debts by payments or spaced out advance payments; or

c) sales made because an isolated event that can not be controlled by the company, is unrepeatable and could not be reasonably anticipated by the society.

The fair value represents a more adequate evaluation method than the depreciated cost for most of financial assets. Investments kept until maturity are an exception, only in case the company has the declared intention to keep them until maturity.

A company does not have a proved capacity to keep until maturity an investment in a financial asset with fixed maturity date if any of the following conditions are fulfilled:

a) it does not have available financial resources to continue financing the investment until maturity;

b) it is subject to a legal restriction or to a restriction that might reenter the discussion its intention to keep the financial asset until maturity; (despite all these, the issuer buying option does not necessarily reenter the discussion the company's intention to keep the financial asset until maturity).

A company evaluates its intention and capacity to hold until maturity its investments kept until maturity not only the moment it buys these financial assets but also at every balance sheet date. If, because of a change of intention or capacity, it is no longer appropriate to register an investment kept until maturity in the depreciated cost, it has to be reevaluated at its fair value, and the difference between its book value and its fair value has to be registered.

Similarly, when an accurate evaluation became possible for an asset, whom such an evaluation wasn't previously possible, that asset must be re-evaluated at the fair value, and the difference between the book value and the fair value must be registered.

If, because of some change in the intention or capacity of keeping (storage) or in the rare cases when a right evaluation of the fair value isn't possible any more, or the two previous accounting periods ended, it became adequately that a financial asset be registered at the depreciated cost and not at the fair value, the fair book value of this asset at that date becoming its new depreciated cost. Any previous profit or loss generated by that asset, registered directly in the equity capital must be registered as follows:

for a financial asset with fixed maturity, a previous profit or loss that was directly registered in the equity capital must be depreciated on the investment's lifetime left. Any difference 
between the new depreciated cost and the mature value must be depreciated in the financial asset's lifetime left, as a return adjustment, similarly to the premium and discount amortization.

for a financial asset without fixed maturity, a previous profit or loss that was directly registered in the equity capital must be maintained until the date of the financial asset's sale or discharge through another way - the date when it must be included in the establishment of the net profit or net loss.

\section{The subsequent evaluation of the financial debt}

After the initial admission, a company must evaluate at the depreciated cost all the financial debts, other than the transaction debts and derived financial instruments that are debts. After the initial admission, a company must evaluate the transaction debts and derived financial instruments that are debts at the fair value, excepting a derived debt linked to and it must be evaluated at the cost. The financial debts that are designed as coverage elements against the risks are evaluated according to the rules of the risk coverage accounting.

\section{The evaluation at the fair value}

The fair value of a financial instrument could be credible evaluated, if:

- $\quad$ the reasonable estimations of the fair value for that instrument doesn't fluctuate in a significant interval or

- $\quad$ the probabilities of the different estimations inside the interval may be reasonably evaluated and used in the fair value estimation.

The situations when the fair value can be credibly evaluated comprise:

- a financial instrument which for there is a quotation published on an active market of securities;

- $\quad$ a debt instrument that was quoted by an independent evaluation agency and whom cash-flow can be reasonably estimated and

- a financial instrument which for there is an appropriate evaluation model and the necessary information for this model can be correctly evaluated because they come from the active markets.

The evaluation techniques must take into account the hypothesis that the market participants will use regarding the rate of the foresee payments, the rates of the losses from loans, the interest and the discount rates.

Essential for the fair value defining is the hypothesis that a company carries on its activity continuously without any intention or need to end it, to reduce significantly the dimension of its operations or to undertake a transaction in unfavourable conditions.

Therefore, the fair value isn't the value that a company will receive or pay in a forced transaction, involuntary liquidation or fortuitous sale. Despite all these, a company take into account its current conditions when determines the fair values for its financial assets and debts. For example, the fair value of a financial asset that the company decided to sale in order to obtain liquidities in very short time is determined by the value that the company expects to obtain from such a sale. The feasible amount from an immediately sale will be affected by factors such as the current liquidity and the market depth for that asset.

The existence of some quotations published on an active market represents normally the best indication of the fair value. For an owned asset or a debt which is to be issued the price quoted on the market is usually the daily purchase cost, and for an asset which is to be purchased or a debt which is to be owned, the selling price. When the purchase and selling prices aren't available, the price of the most recent transactions can indicate the current fair value on condition that there isn't any significant change of the economic conditions between the transaction date and financial 
reporting date. When a company correlated its assets and liabilities positions, it can accordingly use the average of the market prices as support for the establishment of the fair value.

If the market of a financial instrument isn't an active market, it might be necessary the adjustment of the price published quotations in order to attend to a credible evaluation of the fair value. If there is no frequent activity on the market, the market isn't yet functional (for example some of the markets outside the stock exchange) or the transactions volume is low comparatively to the number of the transaction units of the financial asset that has to be evaluated, the market quoted prices can not be an indicative of that asset' fair value. In some occasions, when the traded volume is relatively low, a price quotation for a greater volume may be available from the market maker of that instrument. In another circumstances as well as when a quoted market price isn't available, there can be used estimation techniques in order to establish the fair value with a sufficiently accurate degree for satisfying the requirements IAS 39. The well settled techniques on the financial markets take into account the current market value of another instrument that is substantial similar, the analysis of the discounted cash-flow and models for the settlement of an option price. In the implementation of the discounted cash-flow analysis, a company uses the discount rate equivalent to the predominant rate(s) of return for the financial instruments that have substantially the same terms and characteristics, including the loan category of the debtor, the term left during which the contractual interest rate is fixed, the term left for the repayment of the principle and the currency of payments.

If there is no market price for a financial instrument take as a whole but there are markets for its components, the fair value is based on the re-evaluated market prices. If there is no market for a similarly financial instrument, the fair value is based on the market price of the similarly financial instrument.

\section{Bibliography:}

1. $\quad$ Feleaga N., Malciu L., Bunea St., The basis of accountancy - an European and international approach, Economic Publishing House, Bucharest 2002.

2. Feleaga N., Malciu L., Accounting policies and options, Economic Publishing House, Bucharest 2002.

3. Nicolae Todea, Financial accountancy university course, Aeternitas Publishing House, Alba Iulia 2006.

4. *** Accountancy, Expertise and Business Audit Magazine, collection 2005 - 2007, CECCAR Publishing House, Bucharest.

5. $* * *$ International Standards in Accountancy, Economic Publishing House Bucharest.

6. $* * *$ Minister for Public Finance Order no.1752 from November 17th 2005 for approving the accounting regulations according to European norms ( Published in OJ 1080 from November 30th.2005)

7. $* * *$ Practical Guide for applying accounting Regulations according to Norm IV of the Economic European Communities and the International Standards in Accountancy applicable to institutions settled and monitored by National Securities Commission, approved by the Order of the Minister for Public Finance and the President of National Securities Commission no. $1742 / 106 / 2002$.

8. Bannock, Graham; Manser, William: International Finance English-Romanian Dictionary, Universal Dalsi Publishing House, Bucharest, 2000;

9. Collin, P.H.; Jollife, Adrian: Accounting English-Romanian Dictionary, Universal Dalsi Publishing House, Bucharest, 2000; 
10. Epstein, Barry J.; Mirza, Abbas Ali: IFRS 2005 - Interpreting and applying Accounting and Financial Reference International Standards (translation from English language), BMT Publishing House, Bucharest, 2005;

11. $* * *$ Speciality articles taken from the four international financial-accountancy professional services websites ("The Big Four") - Ernst \& Young, PriceWaterhouseCoopers, KPMG and Deloitte \& Touche Tohmatsu; websites.

12. *** Speciality articles from IASB (www.iasb.org) and FASB (www.fasb.org.) 